\title{
Chemically Modifying Vegetable Oils to Prepare Green Lubricants
}

\author{
Gobinda Karmakar ${ }^{1}$, Pranab Ghosh ${ }^{1}$ and Brajendra K. Sharma ${ }^{2, *}$ \\ 1 Natural Product and Polymer Chemistry Laboratory, Department of Chemistry, University of North Bengal, \\ Darjeeling 734013, India; gobinda.chem@gmail.com (G.K.); pizy12@yahoo.com (P.G.) \\ 2 Illinois Sustainable Technology Center, Prairie Research Institute, University of Illinois, Urbana-Champaign, \\ 1 Hazelwood Drive, Champaign, IL 61820, USA \\ * Correspondence: bksharma@illinois.edu; Tel.: +1-217-265-6810
}

Received: 13 September 2017; Accepted: 4 November 2017; Published: 7 November 2017

\begin{abstract}
Chemically modifying vegetable oils to produce an alternative to petroleum-based materials is one of the most important emerging industrial research areas today because of the adverse effects of petroleum products on the environment and the shortage of petroleum resources. Biolubricants, bioplasticizers, non-isocyanate polyurethanes, biofuel, coating materials, biocomposites, and other value-added chemicals can easily be produced by chemically modifying vegetable oils. This short review discusses using vegetable oils or their derivatives to prepare lubricants that are environmentally safe. Chemically modified vegetable oils are generally used as base fluids to formulate environmentally friendly lubricants. Reports of their application as sustainable additives have attracted special attention recently because of their enhanced multifunctional performances (single additives perform several functions, i.e., viscosity index improver, pour point depressant, antiwear products) and biodegradability compared with commercial additives. Here, we have reviewed the use of chemically modified vegetable oils as base fluids and additives to prepare a cost-effective and environmentally friendly lubricant composition.
\end{abstract}

Keywords: vegetable oil; triglyceride; chemical modification; biolubricant; base stock; additive

\section{Introduction}

Producing materials from renewable feed stocks that are useful to various industrial fields as alternatives to depleting petro-originated resources has attracted considerable attention in recent years. Vegetable oils (VOs) have low ecotoxicity and are readily available and biodegradable. They can be used to produce a variety of environmentally safe chemicals that can compete or even surpass the performance of the existing petroleum-based materials. Materials obtained from vegetable oils (edible or nonedible), such as soybean oil, sunflower oil, palm oil, rapeseed oil, castor oil, and vernonia oil, have an application in various fields, including foods, fuels (biofuels), biolubricants, coatings and paints, adhesives, cosmetics, pharmaceuticals, plasticizers, and construction materials. This review highlights the application of vegetable oils to formulate biolubricants.

Lubricants are the materials (generally liquids, but may be solids or semi-solids) used to lubricate machinery parts to reduce friction and increase their lifetimes. Lubricants have a significant role in tribology, and are formulated from a range of base fluids and chemical additives. Depending on the nature of the base oil, which is the main component of lubricants, they might be categorized as mineral (petroleum origin), synthetic (e.g., polyalphaolefins, polyalkylene glycols, synthetic esters, silicones, etc.), or as a biolubricant/green lubricant. Mineral lubricants, currently the most commonly used commercial lubricants around the world, are a complex mixture of paraffinic (linear/branch), olefinic, naphthenic, and aromatic hydrocarbons of 20 to 50 carbon atoms. They are quite stable (higher oxidation stability) and less expensive than other types of lubricants. However, mineral lubricants 
have poor biodegradability and release toxic materials into the environment. As compared with vegetable-based lubricants, mineral lubricants have lower viscosity indices, higher boundary friction coefficients, and a higher volatility. Moreover, the non-renewable petroleum resources used to produce mineral lubricants are depleting. In order to address the problems associated with petro-based mineral lubricants, the demand to produce environmentally acceptable lubricants from renewable resources is increasing. Lubricant additives that are produced from petroleum resources such as acrylates and zinc dialkyldithiophosphates (ZDDP) create many materials that are harmful to the environment, including heavy metals and sulfur compounds [1,2]. The friction modifier, such as molybdenum dithiocarbamate complexes used in solid lubricants, releases heavy metals and sulfur compounds, and their activity decreases with fluid aging [3]. Therefore, interest in research on bio-based lubricant additives is also increasing. Synthetic lubricants have advantages over mineral lubricants, such as they are environmentally benign, have a higher viscosity index, lower pour points, and higher oxidative stability. However, synthetic lubricants also have some disadvantages, as mentioned below:

- $\quad$ They are more expensive than mineral lubricants [4];

- They are relatively more toxic than vegetable oil-based lubricants;

- They are less readily biodegradable than vegetable oil-based lubricants;

- They have a lower friction tolerance and their exhausts pose problems in the environment;

- They do not work well with mineral oils.

Although biolubricants produced from vegetable oils are more costly than mineral lubricants, they are a promising alternative to synthetic and mineral oil-based lubricants because of their specific functional attributes such as high viscosity index, good lubricity, superior anticorrosion properties, high flash point, high biodegradability, and low aquatic toxicity [5,6]. With its long fatty acid chain and polar end groups, the structure of vegetable oil is amphiphilic in nature. Oils are suitable as a base stock for easily blending different kinds of environmentally acceptable additives, and are used as both boundary and hydrodynamic lubricants. Additives prepared from vegetable oils showed excellent tribological properties and performed well at extreme pressures. Li et al. [7] illustrated the application of an extract of natural garlic oil as a high-performing and environmentally friendly extreme pressure additive in lubricating oils. Ossia et al. [8] showed that eicosanoic and octadecanoic acids present in castor and jojoba oil enhanced the tribological and oxidation stability of castor and jojoba oil as well as mineral oil base-stocks. Erhan et al. [9] disclosed the use of poly (hydroxy thioether) vegetable oil derivatives as antiwear/antifriction additives for environmentally friendly industrial oils in automotive applications. Different methods of making fatty acid ester derivatives from unsaturated fatty acids through formation of their epoxides have also been described by Erhan et al. [10,11]. Doll et al. [12] disclosed a novel process of preparing chemically modified triglycerides by the reaction of epoxidized triglyceride oils or alkyl esters thereof with phosphorus-based acid hydroxide or esters. The phosphorus-containing triglyceride derivatives so produced have a found utility as antiwear/antifriction additives for industrial oils and automotive applications. Biswas et al. [13] described a method of preparing nitrogen-containing fatty acid derivatives by reacting epoxidized fatty acids, their esters, or triglyceride oils with amines of cyclic or aromatic hydrocarbons. These fatty acid derivatives are used as antiwear/antifriction additives for industrial oils and automotive applications. Heise et al. [14] described the preparation of boron-containing fatty acid derivatives by reacting epoxidized fatty acids, their esters, or triglyceride oils with borate compounds which have a found application as antifriction additives in the automotive industry.

Erickson et al. [15] disclosed the methods for preparing lubricant additives (antiwear) by combining triglyceride vegetable oils (meadowfoam oil, rapeseed oil, or crambe oil) with at least one sulfurized vegetable oil and a phosphite adduct of vegetable oil. The same group also reported the preparation of bio-based lubricant additives that comprise a combination of meadowfoam oil as a triglyceride or a wax ester, sulfurized triglyceride meadowfoam oil or sulfurized wax ester of meadowfoam oil, and phosphate adducts of triglyceride meadowfoam oil or wax ester of meadowfoarn 
oil [16]. Few bio-based additives showed multifunctional performances [17-20]. Therefore, we do not need to blend different kinds of additives with the base stock. However, there are some limitations in using vegetable oils. The major component of VOs is a triglyceride of long-chain fatty acids of mostly unsaturated carbon atoms. The double bonds of the fatty acid chains are mostly unconjugated. They have low thermo-oxidative stability, poor bio-resistance, poor hydrolytic stability, and poor fluidity at lower temperatures [21-23]. Therefore, they cannot be used directly as lubricant-based stocks/additives. The presence of bis-allylic protons in the chain makes VOs very prone to oxidative degradation [24]. This ultimately results in an insoluble deposit formation in vegetable oils which increases oil acidity, viscosity, corrosion, and volatility. Another drawback of VOs is their higher cost of production compared with mineral lubricants. This cost currently prohibits the complete replacement of mineral lubricants by biolubricants for commercial purposes. These limitations can, however, be mitigated by chemically modifying VOs to reach a desirable performance level without increasing the cost. Extensive research is being conducted worldwide to produce lubricant base stocks or additives from vegetable oils more economically [25-28].

\section{Chemical and Physical Properties/Characteristics of Vegetable Oils}

Chemical and physical properties of VOs mainly depend on the composition of unsaturated fatty acids, which in turn depend on the climate of cultivation, genetic modification of the oil-producing crops, and so forth. Fatty acids present in vegetable oils are mostly long and straight-chained with unconjugated double bonds, and most of these unsaturated fatty acids possess a cis configuration (Figure 1). However, some fatty acid chains, such as ricinoleic and vernolic acids, contain hydroxyl and epoxy functional groups, respectively [29,30]. In the triglycerides of vegetable oils, such as soybean, sunflower, palm, linseed, etc., oleic acid, linoleic acid, and linolenic acid predominate. In castor oil and vernonia oil, however, ricinoleic acid (Figure 2) and vernolic acid (Figure 3) are the major constituents, respectively. Fatty acid compositions of commonly used vegetable oils are listed in Table 1 . The higher the percentage of unsaturation, the better the VOs will be in preparing environmentally acceptable lubricants (base stock/additives). Vegetable oils can be classified as edible or nonedible. Coconut, olive, soybean, sunflower, palm, peanut, canola, corn, and so forth belong to the class of edible oils. Since they are used to formulate biolubricants, their demand is always very high. The non-edible vegetable oils such as neem, castor, mahua, rice bran, karanja, jatropha, linseed etc. are comparatively less expensive and therefore have an advantage over edible oils for the production of biofuel/biolubricants [31-33].

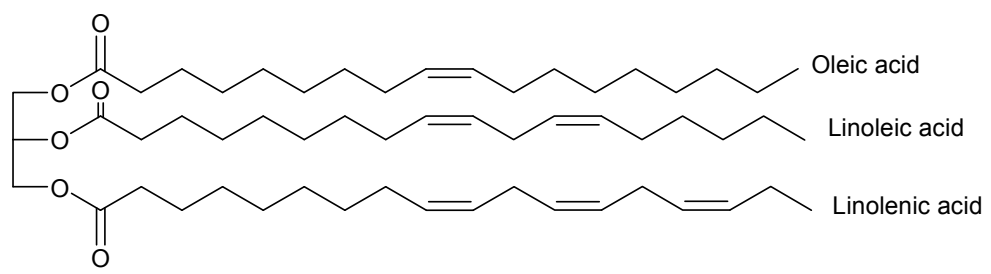

Figure 1. General structure of triglyceride esters of edible vegetable oils.

The percentage of unsaturated fatty acids, which largely varies among different types of VOs, can be determined by measuring the iodine value (IV) [34]. Larger IV values indicate a greater degree of unsaturation per vegetable oil triglyceride. Depending upon the IV values, vegetable oils can further be classified as drying oils (IV > 130), semi-drying oils $(100<$ IV < 130), or non-drying oils $($ IV $<100)$. The more unsaturated the fatty acid, the more susceptible it is to functionalization. Linseed oil, soybean oil, sunflower oil, castor oil, and so forth contain more than $80 \%$ unsaturated acids, and therefore can easily be chemically modified. So the derivatives of these oils are largely applied to formulate biolubricants (base stocks/additives) [17,18,20,21,29]. 
The quality / performance of a biolubricant depends largely on their physical properties, which include the viscosity index [35], pour point [36], flash point, cloud point [37], thermal stability [38], oxidation stability, shear stability [39], iodine value, and density. A better lubricant should have a higher viscosity index, flash point, thermo-oxidation stability, shear stability, and lower pour point and cloud point. The fatty acid compositions of different VOs are listed in Table 2.

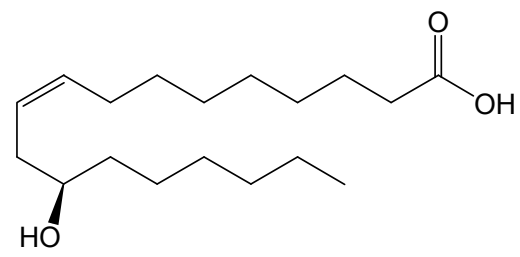

Figure 2. Ricinoleic acid, the major content of castor oil.

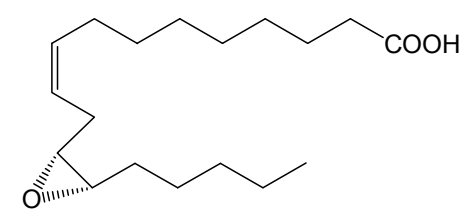

Figure 3. Vernolic acid, the major content of vernonia oil.

Table 1. Fatty acid compositions of commonly used vegetable oils [40-52].

\begin{tabular}{|c|c|c|c|c|c|c|c|c|c|}
\hline Vegetable Oils & C12:0 & C14:0 & C16:0 & C18:0 & C16:1 & C18:1 & C18:2 & $\mathrm{C} 18: 3$ & Others \\
\hline Soybean oil & - & - & $11-12$ & 3 & 0.2 & 24 & $53-55$ & $6-7$ & - \\
\hline Sunflower oil & - & - & 7 & 5 & 0.3 & $20-25$ & $63-68$ & 0.2 & - \\
\hline Rapeseed oil & - & - & $4-5$ & $1-2$ & 0.21 & $56-64$ & $20-26$ & $8-10$ & $9.1(20: 1)$ \\
\hline Palm oil & - & 1 & $37-41$ & $3-6$ & 0.4 & $40-45$ & $8-10$ & - & - \\
\hline Rice bran oil & - & - & $20-22$ & $2-3$ & 0.19 & 42 & 31 & 1.1 & - \\
\hline Cotton seed oil & - & 1 & $22-26$ & $2-5$ & 1.4 & $15-20$ & $49-58$ & - & - \\
\hline Coconut oil & $44-52$ & 13-19 & $8-11$ & $1-3$ & - & $5-8$ & $0-1$ & - & - \\
\hline Corn (Maize) oil & - & - & $11-13$ & $2-3$ & 0.3 & $25-31$ & $54-60$ & 1 & - \\
\hline $\begin{array}{c}\text { Peanut/Ground } \\
\text { nut }\end{array}$ & - & - & $10-11$ & $2-3$ & 0 & $48-50$ & $39-40$ & - & - \\
\hline Sesame oil & - & - & 7-11 & $4-6$ & 0.11 & $40-50$ & $35-45$ & - & - \\
\hline Safflower oil & - & - & $5-7$ & $1-4$ & 0.08 & $13-21$ & $73-79$ & - & - \\
\hline Karanja oil & - & - & $11-12$ & $7-9$ & - & 52 & $16-18$ & - & - \\
\hline Jatropha oil & - & 1.4 & $13-16$ & $6-8$ & - & $38-45$ & $32-38$ & - & - \\
\hline Rubber seed oil & - & $2-3$ & 10 & 9 & - & 25 & 40 & 16 & - \\
\hline Mahua oil & - & - & 28 & 23 & - & $41-51$ & $10-14$ & - & - \\
\hline Tung oil & - & - & 2.67 & 2.4 & - & 7.88 & 6.6 & $80.46 *$ & - \\
\hline Neem oil & - & - & 18 & 18 & - & 45 & $18-20$ & 0.5 & - \\
\hline Castor oil & - & - & $0.5-1$ & $0.5-1$ & - & $4-5$ & $2-4$ & $0.5-1$ & $83-85^{\#}$ \\
\hline Linseed oil & - & - & $4-5$ & $2-4$ & $0-0.5$ & 19.1 & $12-18$ & 56.6 & - \\
\hline Olive oil & - & - & 13.7 & 2.5 & 1.8 & 71 & 10 & $0-1.5$ & - \\
\hline
\end{tabular}

* Alpha-eleostearic acid. \# Ricinoleic acid. 
Table 2. Physical properties of vegetable oils.

\begin{tabular}{|c|c|c|c|c|c|c|c|}
\hline Vegetable Oils & $\begin{array}{l}\text { Iodine } \\
\text { Value }\end{array}$ & $\begin{array}{c}\text { Pour } \\
\text { Point }\left({ }^{\circ} \mathrm{C}\right)\end{array}$ & $\begin{array}{c}\text { Cloud } \\
\text { Point }\left({ }^{\circ} \mathrm{C}\right)\end{array}$ & $\begin{array}{c}\text { Kinematic } \\
\text { Viscosity at } 40{ }^{\circ} \mathrm{C} \\
\left(\mathrm{mm}^{2} / \mathrm{s}\right)\end{array}$ & $\begin{array}{c}\text { Flash } \\
\text { Point }\left({ }^{\circ} \mathrm{C}\right)\end{array}$ & $\begin{array}{c}\text { Density at } \\
15^{\circ} \mathrm{C}\left(\mathrm{g} / \mathrm{cm}^{3}\right)\end{array}$ & Ref. \\
\hline Soybean oil & $138-143$ & -12 & -4 & 29 & 254 & 0.914 & [53-55] \\
\hline Sunflower oil & $125-140$ & -15 & -9.5 & 36 & 274 & 0.916 & {$[53-56]$} \\
\hline Rapeseed oil & 98-105 & -15 & -2 & 35 & 246 & 0.912 & [53-55] \\
\hline Palm oil & $48-58$ & 23.6 & 25.2 & 39.4 & 252 & 0.919 & [57] \\
\hline Rice bran oil & 103 & 13 & 16 & 38.2 & 184 & 0.906 & [41] \\
\hline Cotton seed oil & 90-119 & -4.5 & -0.5 & 34 & 234 & 0.918 & {$[41,56]$} \\
\hline Coconut oil & $8-11$ & 12.7 & 13.1 & 27 & 266 & 0.918 & [53-56] \\
\hline $\begin{array}{l}\text { Peanut/Ground } \\
\text { nut/Arachis oil }\end{array}$ & 84-100 & -7 & 4.5 & 40 & 271 & 0.903 & $\begin{array}{c}{\left[\begin{array}{c}53-55, \\
58]\end{array}\right.}\end{array}$ \\
\hline Sesame oil & 104-116 & -11 & -8 & 36 & 260 & 0.918 & $\begin{array}{c}{[41,56,} \\
58]\end{array}$ \\
\hline Karanja oil & $81-90$ & -4 & 2 & 38.8 & 212 & 0.9358 & {$[48,49]$} \\
\hline Jatropha oil & $82-98$ & -6 & 11 & 34 & 225 & 0.94 & [53-55] \\
\hline Rubber seed oil & 104 & 18 & 25 & 33.89 & 228 & 0.928 & {$[59,60]$} \\
\hline Mahua oil & $58-70$ & 11 & 20 & 37.18 & 238 & 0.945 & [61] \\
\hline Neem oil & 81 & 7 & 13 & 35.8 & 200 & 0.918 & [52] \\
\hline Castor oil & $83-86$ & -21 & -18 & 251 & 229 & 0.960 & [53-56] \\
\hline Linseed oil & 168-204 & -15 & 5 & $26-29$ & 241 & 0.938 & {$[41,58]$} \\
\hline Safflower oil & 145 & -7 & -2 & 28.3 & 260 & 0.914 & [53-55] \\
\hline Olive oil & $75-94$ & -14 & -11 & 39 & 177 & 0.918 & {$[41,56]$} \\
\hline
\end{tabular}

\section{Chemical Modification/Derivatization of Vegetable Oils}

Vegetable oils used directly as base stocks or lubricant additives cannot perform satisfactorily. They have lower thermo-oxidative stability, higher viscosity, and lower volatility. They burn incompletely and form deposits in fuel injectors of engines due to a high viscosity (about 11 to 17 times higher than diesel fuel) and low volatility. Therefore, before using vegetable oils as biofuel/biolubricants, they must be chemically modified. This can be performed in two different ways: reactions at the carboxyl groups of fatty acids/esters/triglycerides of vegetable oils or reactions at the olefinic functionalities of the fatty acid chain. Transesterification of VOs is the most important initial step in producing biofuel/lubricants. Fatty acid alkyl esters along with glycerol are produced by transesterification of VOs. There are several examples in which transesterified VOs were used as a biofuel/biolubricant [62-65]. These fatty acids can be further converted into their derivatives by one or multistep strategies involving numerous reactions to produce various types of lubricants/additives based on industrial needs. Glycerol obtained from triglyceride esters can also be converted into water-based lubricant additives [66] along with other different essential chemicals.

Functionalization of the olefin functional groups of unsaturated fatty esters or free fatty acids of vegetable oils can be performed by various reactions such as epoxidization, carbonation, maleation, acrylation, hydroxylation, hydroformylation, reduction, thiol-ene addition, and polymerization to produce plasticizers, polyurethanes, adhesives, paints, coatings, and envirsonmentally friendly additives for lubricants [40,67-71]. The different modes of chemical vegetable oil transformation to produce base stocks/additives for biolubricants are discussed below.

Transesterification: Transesterification of vegetable oils with different alcohols produces fatty acid alkyl esters (and glycerol) that can be used as biofuel or biolubricants (Figure 4). Transesterification reactions can be catalyzed by both homogeneous [72,73] and heterogeneous catalysts [74] (alkalies and acids). In a transesterification reaction, homogeneous alkali catalysts are commonly used. In most cases, short-chain alcohols such as methanol/ethanol are used (for biodiesel production) as a base, and either potassium or sodium hydroxide is used as a catalyst. Potassium hydroxide is found to be more suitable for ethyl ester biodiesel production, but either base can be used for methyl ester production. As the base catalyst is mostly used for biodiesel production, fats and oil used for this purpose must be free of fatty acids (i.e., a good quality feedstock). Low quality feed stocks, including non-edible vegetable oils, animal fats, waste cooking oils, and grease, contain a significant amount of free fatty acids (FFAs) [75]. When FFAs are present, the base catalyst cannot be used because of 
soap formation. Acid catalysts work much more slowly than a base catalyst in a transesterification reaction [76]. Moreover, because of the corrosive nature of acid catalysts; expensive acid-resistant reactors must be used. Therefore, in order to convert a low quality feedstock into biodiesel, first the FFAs present in the feedstock should be converted into esters with an acid catalyst to obtain a mixture of fatty acid alkyl esters and triglycerides. The esters in the second step are transesterified with methanol/ethanol catalyzed by a base to obtain biodiesel. An acid-catalyzed process, although slow and requiring a higher temperature, can be used with any type of feedstock. It is mostly used for transesterification of high free fatty acid-containing feedstock such as yellow grease, crude palm oil, and karanja, as in these cases a base catalyst cannot be used. Regardless of whether an acid or a base catalyst is used, homogeneous catalysts present certain disadvantages. Homogeneous catalysts require a high energy consumption and are corrosive (acid catalysts are more corrosive than base catalysts). They are also difficult to recover from the solution. Because of these disadvantages, the application of heterogeneous solid catalysts in the transesterification process has become more popular recently. Heterogeneous acid catalysts, such as ion-exchange resins (Amberlyst-15, Nafion) [77,78], sulfated inorganic oxides [79], inorganic superacids $\left(\mathrm{WO}_{3} / \mathrm{ZrO}_{2}, \mathrm{WO}_{3} / \mathrm{ZrO}_{2}-\mathrm{Al}_{2} \mathrm{O}_{3}\right)$ [80] and basic catalysts such as alkaline earth oxides $(\mathrm{CaO}, \mathrm{MgO})$, alkali-supported catalysts $\left(\mathrm{KF} / \mathrm{K}_{2} \mathrm{CO}_{3}\right.$ or $\mathrm{KNO}_{3}$ supported $\mathrm{Al}_{2} \mathrm{O}_{3}$ ) [81], zeolites [82] and guanidine-supported catalysts [83] have attracted considerable interest recently. Extensive research on preparing the biodiesel or lubricant-based stocks/additives through transesterification of vegetable oils is ongoing [61-65]. Sulek et al. showed that the friction coefficient of diesel fuel was decreased by $20 \%$ and wear by two-fold due to blending fatty acid methyl esters derived from rapeseed oil with the fuel [84]. A significant reduction of wear scar diameter from the addition of $5 \%$ rapeseed oil methyl esters in diesel fuel was disclosed by Sukjit et al. [85]. It was reported that the lubrication performance of diesel base oils was improved when palm oil methyl esters are blended [86,87]. Masjuki and Maleque (1997) reported that adding 5\% (v/v) of palm oil methyl ester in the base oil lubricant resulted in a low wear rate of an EN31 steel ball bearing [88]. Malavolti et al. [89] has synthesized biodiesels through the transesterification of castor oil with various alcohols in the presence of trimethylchlorosilane (TMSCl) as an acidic mediator. The potential use of castor oil methyl esters as biolubricants, with its high viscosity, low pour point, and good lubricity, was explained by Madankar et al. [90].

Glycerol obtained as a co-product in the transesterification process can be converted into biofuels, green additives for water-based lubricants, foods, pharmaceuticals, cosmetics, liquid detergents, antifreeze, and toothpaste by numerous reactions including esterification [87], acetalization [40], oxidation [40], hydrogenolysis [40], internal dehydration, and oxidative carbonylation [40]. Low-cost glycerol aqueous solutions with a good biocompatibility and low temperature properties have reportedly been applied in multiple fields as a better green lubricant [91]. High molecular weight polyglycerol derivatives, useful as thickening agents for water-based lubricants, are prepared by oxyalkylation of a polyglycerol with ethylene oxide or a mixture of ethylene oxide and propylene oxide [92].

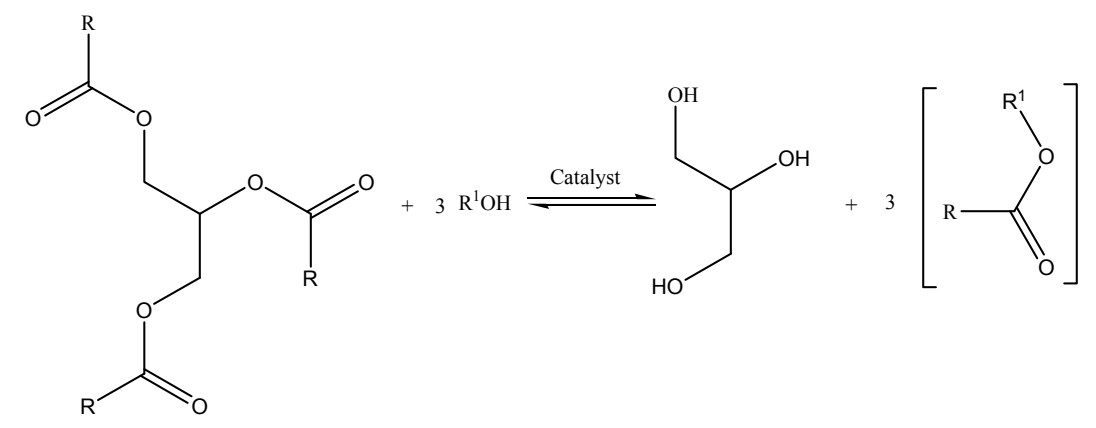

Figure 4. Transesterification of triglyceride ester of fatty acids. 
Hydrolysis: The hydrolysis of triglyceride esters or the fatty esters produced from them by the transesterification process produces free fatty acids. These fatty acids are converted into their corresponding esters, used as biolubricants, when treated with higher alcohols (C8 to C14) in the presence of a suitable catalyst [93]. The process can be successfully used as an alternative method for producing biodiesel/biolubricants from waste cooking oils/fats, which otherwise have no immediate potential use [94]. The hydrolysis of oils, prior to saponification, provides the possibility of overcoming many problems associated with the recovery of the by-product glycerol. Besides biodiesel production, fatty acids are major components used to prepare a wide variety of products such as soaps, surfactants, lubricants, plasticizers, paints and coatings, pharmaceuticals, and foods and agricultural, industrial, and personal care products. Different catalysts have been used to hydrolyze VOs/fatty esters. Avisha et al. discovered a novel synthetic method to produce biolubricants by using the two-step process of Candida rugosa lipase-mediated hydrolysis of waste cooking oil (WCO) to FFAs followed by Amberlyst $15 \mathrm{H}$ esterification of them with octanol [95]. The octyl esters thus produced have been used as the desired biolubricant. Vescovi et al. also produced biodiesel from WCO via enzymatic hydrolysis followed by esterification [96]. Waghmare et al. [97] synthesized biodiesel by ultrasound-assisted enzyme catalyzed hydrolysis of waste cooking oil under solvent-free conditions. Soares et al. [98] manufactured biodiesel from soybean soap stock acid oil by hydrolysis in subcritical water, followed by lipase-catalysed esterification. Luo et al. reported the hydrolysis of vegetable oils catalyzed by $\mathrm{SO}_{3} \mathrm{H}$-functional Brønsted acidic ionic liquids at a moderate temperature and reaction time [99]. Syaima et al. has reported the synthesis of the biolubricant from palm oil mill effluent (POME) using enzymatic hydrolysis and non-catalytic esterification [100]. They studied the effect of different parameters such as temperature, agitation speed, enzyme loading, POME concentration, and the ratio of alcohol to fatty acids on the rate of hydrolysis and esterification reaction. The optimum hydrolysis rate was achieved at $40{ }^{\circ} \mathrm{C}$ with enzyme loading at $20 \mathrm{U} / \mathrm{mL}, \mathrm{pH} 7.0$, and the concentration of POME 50\% (v/v). They also evaluated the viscosity and density of the biolubricants.

Fatty acids can easily be converted into their derivatives such as amides and amines or reduced into alcohols. These compounds are very significant for industrial application, especially as an antiwear lubricant additive.

Fatty amines: Fatty amines, obtained from fatty acids or fatty acid alkyl esters by reaction with ammonia at a high temperature followed by dehydration and hydrogenation, are used in the lubricant industry as a friction modifier in engine oils [101,102]. The preparation of fatty amines occurs in two steps (Figure 5). In the first step, fatty acids or fatty acid alkyl esters are treated with ammonia in the presence of a dehydration catalyst to form fatty nitriles. The nitriles are hydrogenated into fatty amines by a metal catalyst in the second step. Oleic acid, when treated with excess ammonia at $408 \mathrm{~K}$ and 35 bar, yields oleonitrile, which under catalytic hydrogenation at $413 \mathrm{~K}$, gives stearyl amine with a yield close to $96 \%[40,103]$. These additives are far better than the commercial ZDDP type antiwear additives.

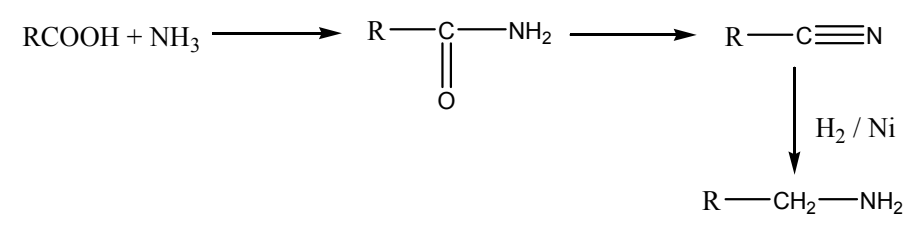

Figure 5. Preparation of fatty amine.

The use of a partly neutralized fatty amine salt as a friction modifier for lubricating oil, especially for an internal combustion engine, was claimed by Lundgren [104,105]. The inventor found that a partially neutralized fatty amine salt works as an excellent friction modifier for a lubricating oil to be used in an internal combustion engine or a gearbox. Laufenberg et al. [106] disclosed the production of lubricant concentrates and aqueous lubricant solutions containing at least one polyamine derivative 
of a fatty amine and/or a salt of such an amine for lubricating, cleaning, and disinfecting automatic chain and belt conveyor systems.

Fatty amides: Fatty amides can be prepared by base catalyzed aminolysis of fatty acids or esters using ammonia or a primary or secondary amine (e.g., dimethylamine, ethanolamine, isopropanolamine, or diethanolamine). These amines are valuable in preparing a wide variety of value-added materials, such as cleaners, fabric treatments, hair conditioners, personal care products (liquid cleansing, conditioning bars, oral care), antimicrobial compositions, agricultural uses, and most importantly, as an antiwear additive in oil field applications. Pramanik et al. [107] reported the effect of soybean oil-based fatty amides as a rheology modifier additive in coatings. It has been reported that the fatty amide formed by reacting fatty acids with diethanolamine was used as an active ingredient to manufacture dry cleaning soaps, fuel oil additives, rust inhibitors, textile scouring, dye leveling agents, and woolen cloths $[108,109]$. Amides prepared from hydrogenated soybean oil or coconut oil glycerides and a hydroxyalkyl polyamine have been reported as an ingredient useful in lubricating and softening textile materials such as rayon fabrics [110]. The lubricity of fuels can be increased by blending and adding fatty amides. Gentry et al. disclosed the application of alkanolamide of a fatty acid, an alkanolamide of a modified fatty acid, or a mixture as lubricity aids in low sulfur diesel fuels and spark ignition fuels [111]. It was reported that a modified mixed amide derived from the reaction of a substantially saturated fatty acid triglyceride with a deficiency of dialkanolamine, either alone or in combination with a sulfurized substantially unsaturated fatty acid triglyceride, were used as an improved friction modifier or antiwear additive to crankcase oils [112].

Fatty alcohols: Fatty alcohols or their derivatives can be used for the production of different industrially useful materials such as biolubricants, plasticizers, surfactants, etc. Fatty alcohols are easily obtained from fatty esters of vegetable oils/natural fats by catalytic reduction reaction. The selective reduction of unsaturated esters to unsaturated alcohols is generally performed by a metal-based solid hydrogenation catalyst under high pressure and temperature. Methyl oleate was converted into the corresponding unsaturated alcohol selectively when treated with Ru-Sn-B/ $\mathrm{Al}_{2} \mathrm{O}_{3}$ catalysts at a high temperature (523-573 K) and pressure (25-35 MPa) in a liquid-phase slurry-bed process [113]. Giraldo et al. developed an environmentally friendly Ni-Cu-Zeolite as a bimetallic catalyst for selective hydrogenation of the preparation of palm oil-based fatty alcohols [114]. The larger chain alcohols are suitable for producing biofuels and as non-ionic surfactants or emulsifiers, as well as emollients and thickeners in the cosmetics and food industries. Mueller et al. disclosed information on the application of linear and/or branched fatty alcohols (containing at least 12 carbon atoms) or mixtures of such fatty alcohols with carboxylic acid esters as a lubricating additive in water-based drilling fluids used in geological exploration [115]. The fatty alcohol-based lubricants or lubricant systems are particularly suitable for use in water-based alkali metal silicate drilling muds, which are known to be distinguished by comparatively high $\mathrm{pH}$ values. These fatty alcohols are also used as an antifoam additive for lubricants.

Epoxidation of fatty acids/esters and their application as a biolubricant: One of the most important steps in preparing a biolubricant (base stock and/or additive) from vegetable oils is the epoxidation of its olefinic functionalities. The epoxidation of free fatty acids/esters/vegetable oils can be carried out in the presence of peracids through an in-situ or ex-situ process by varying the reaction parameters: reactant molar ratio, temperature, nature of the solvent, presence or absence of a catalyst (mineral acids/ion exchange resins), stirring speed, type of peroxyacid (peracetic, performic, m-chloroperbenzoic acid), mode and rate of the addition of $\mathrm{H}_{2} \mathrm{O}_{2}$ /acetic or formic acid, the reaction period, and contacting patterns (batch/semi-batch mode/azeotropic distillation) [116-118]. To avoid the corrosive nature and undesirable side reactions (ring opening of oxirane) of mineral acids, heterogeneous catalyst systems such as acidic ion exchange resins [119], transition metal-based catalysts such as Ti-silica [120], $\mathrm{Nb}(\mathrm{V})$-silica [121], sulfated-SnO ${ }_{2}$ [122] and polyoxometalate [123] have become known recently for their ability to perform the epoxidation reaction. To characterize the epoxidation products, different analytical methods, such as measurement of the iodine value, 
oxirane content, FTIR, ${ }^{1} \mathrm{H}$ NMR, and ESIMS are performed. Iodine values of the FAMEs (fatty acid methyl esters) and vegetable oils expressed as gram per 100-gram sample (g per $100 \mathrm{~g}$ ) are generally determined according to Wij's method [124]. Alves et al. (2013) found that modified vegetable oils such as epoxidized sunflower and soybean oils resulted in a lower friction coefficient than the mineral and synthetic oils [125].

Because of their higher reactivity, the oxirane rings of the epoxides can easily be opened by different reagents such as acids, alcohols, thiols, and amines to provide different value-added compounds such as biolubricants (base stocks/additives), bio-plasticizers, and other industrially useful chemicals. The epoxidized vegetable oils/fatty esters are used to prepare antiwear/antifrictional additives for lubricants. Because of their higher solubility in biodegradable vegetable oils and synthetic esters, these additives showed a considerably better performance than conventional petroleum-based additives. Schafer et al. described the development of corrosion-protection additives from an epoxidized methyl ester of an unsaturated fatty acid and a sulphonic acid [126]. Rowland et al. disclosed different antifrictional additives from an epoxidized ester of fatty acids to reduce lead corrosion in lubricants and fuels [127]. Lathi et al. discussed the preparation of lubricant base stock/additives by opening the rings of epoxidized soybean oil with different alcohols (n-butanol, iso-amyl alcohol, and 2-ethylhexanol) followed by esterification of the resulting hydroxy group through alcoholysis using the same catalyst [128]. The furnished lubricants showed significant improvement in pour point values. It was further observed that as the chain length of branched alcohol increased, it gives lower pour point values and 2-ethylhexanol showed lowest pour point value as compared to other alcohols. Hydroxy thio-ether derivatives of vegetable oils prepared by opening the epoxy rings of epoxidized soybean oil with common organic thiols are used as sustainable antiwear/antifrictional additives for lubricants $[129,130]$. The incorporation of sulfur in the triglyceride backbone in this process introduces polar functionalities in the molecule which improved the adsorption power of the derivatives on metal surface resulting in reduced wear and friction coefficient. They showed better antiwear performance compared to commercial additive packages. Ester hydroxy derivatives of methyl oleate, obtained by opening the epoxy rings of epoxidized methyl oleate by different organic acids (propionic, levulinic, octanoic, hexanoic, or 2-ethylhexanoic acid) showed better pour point and cloud point values [28]. They also showed improved thermo-oxidation stability and tribological and lubricity properties when used as lubricant additives. The opening of epoxy rings with different amines produces substituted derivatives of $\beta$-amino alcohols that are used in the medical field as antioxidant derivatives for lubricants [131]. Carbonated derivatives of fatty esters, which are also used to prepare biolubricants and other essential value-added materials, can easily be prepared from epoxy derivatives of fatty esters/vegetable oils [132].

The opening of the epoxy rings of vegetable oils/fatty derivatives to produce different value-added compounds that have an application in the formulation of biolubricants are shown in Scheme 1.

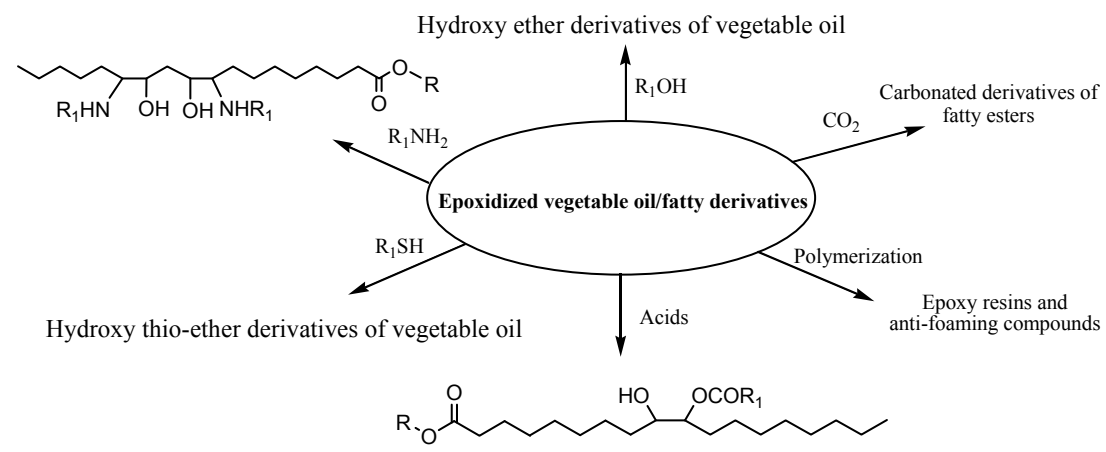

Scheme 1. Epoxidized vegetable oil/fatty derivatives as a starting material to prepare different biolubricants/additives for lubricants. 
Conversion of the olefinic functional groups into cyclic carbonates and the use of different nucleophiles to open the rings: Cyclic carbonates are attractive green intermediates that are non-toxic, biodegradable, and can easily be prepared by coupling carbon dioxide with epoxy fatty esters (Figure 6). Fatty ester carbonates have the physical and chemical properties useful for preparing different valuable chemicals for many applications [132-135]. There are two main benefits of the conversion of fatty acid derivatives/epoxidized oils into cyclic carbonates. The first one is the preparation of novel materials from renewable resources, and the second is recycling and exploiting of carbon dioxide into the value chain. The coupling reaction of epoxides with $\mathrm{CO}_{2}$ is an intensively studied field of research, and various homogeneous and heterogeneous catalysts have been reported for this reaction [133-135]. Han et al. [136] employed imidazolium-based ionic liquids with varied alkyl chain lengths bearing different anions as a heterogeneous catalyst for preparing cyclic carbonates. Tamami et al. reported on the synthesis of carbonated soybean oil from epoxidized soybean oil at an atmospheric $\mathrm{CO}_{2}$ pressure using tetra-n-butylammonium bromide $\left(\left[\mathrm{Bu}_{4} \mathrm{~N}\right] \mathrm{Br}\right)$ as a catalyst [137]. An improved protocol for the synthesis of carbonated oleo compounds was described by Doll et al. [133]. They have synthesized carbonated methyl oleate and carbonated methyl linoleate from epoxy derivatives of fatty esters using supercritical carbon dioxide directly with a catalytic amount of tetrabutylammonium bromide. The synthesized compounds have potential uses as industrial lubricants or fuel additives. Shorter chain linear carbonates are useful as emollients, and longer chain carbonates have been used as lubricants and fuel additives [138].

Schäffner et al. [67] tested simple alkali halides combined with a phase transfer catalyst in the reaction of epoxidized methyl linoleate with $\mathrm{CO}_{2}$ to prepare the respective bis-carbonate. Sodium iodide and 15-crown- 5 as well as the combination of potassium iodide and 18 -crown- 6 were proven to be very active catalyst systems in the model reaction at $100{ }^{\circ} \mathrm{C}, 100 \mathrm{bar}$, and $17 \mathrm{~h}$ with a conversion of $94 \%$ and $90 \%$, respectively [139].

The carbonated ring of the fatty esters can easily be opened by a variety of nucleophiles to produce phthalate-free bio-plasticizers [140], non-isocyanate polyurethane [141], biolubricants [68], adhesives, and many other value-added products.

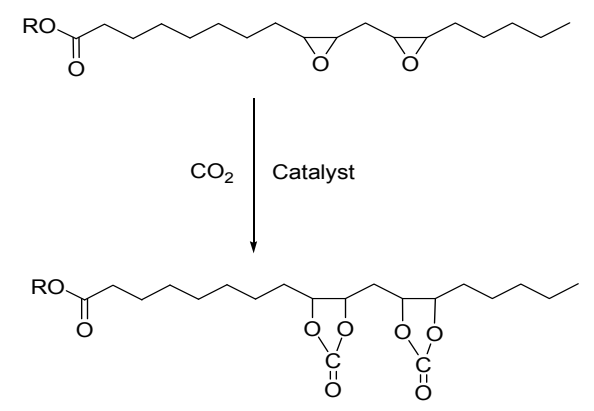

Figure 6. Carbonation of epoxy fatty esters.

Polymerization and preparation of polymer nanocomposites: Biolubricants (additives/base stocks) can also be prepared through homopolymerization of vegetable oils/fatty esters or their epoxy derivatives or copolymerization with suitable co-monomers. Polymerization of vegetable oil or their derivatives can be conducted by different techniques, e.g., cationic, free radical, ring opening, and condensation polymerization. Thermally polymerized soybean oil mixed with additives and diluents was used as a bio-based gear oil [142]. In our previous work, free radical polymerization of vegetable oils and their application as eco-friendly lubricant additives has been discussed [17-19,143,144]. Biresaw et al. [145] described the application of bio-based polyesters as an extreme pressure additive in mineral oil. The synthesis and evaluation of telomerized vegetable oil, sulfurized and phosphorus derivatives of telomerized vegetable oils, and combinations thereof for use as thermal oxidative stability enhancers and viscosity improvers have been reported by Landis [146]. Telomerization 
induces vegetable oil that contains no more than $4 \%$ polyunsaturated fatty acids to help enhance its thermo-oxidative stability. The invention is further related to telomerized triglyceride vegetable oils as a lubricating composition base stock substitute. Recently, relatively new polymerization methods such as acyclic diene metathesis polymerization [147] and ring-opening metathesis polymerization [148,149] of functionalized fatty alcohols have been employed to synthesize vegetable oil-based polymers as well. Polymerization of vegetable oils/derivatives in the presence of different organic or inorganic nanofillers produces polymer nano-composites, which are extensively applied in the automotive industry, especially as an antiwear coating/additive in lubricants [150].

\section{Conclusions}

In this short review we highlighted the chemical transformation of vegetable oils to produce different materials that have an application in the formulation of biolubricants. The study is significant in the present context of increasing global environmental pollution and decreasing petroleum resources. The main advantages of vegetable oil-based lubricants are its high biodegradability and low aquatic toxicity. Recently bio-based lubricants are blended with commercial ones to prepare eco-friendly lubricant compositions. However, we have not yet been able to completely replace the commercial mineral lubricants with bio-based lubricants. This is due to the current lower production of vegetable oils which increases the cost of bio-based lubricants compared with petroleum-based ones Although the vegetable oil-based lubricants (base fluids or additives) are more costly than commercial petroleum-based lubricants, they are emerging as future green products because of their nontoxic and biodegradable nature. These oils have a higher viscosity index, better wear performance, higher flash point, and lower pour point and cloud point than other lubricants. Research is still being conducted to develop a new methodology for manufacturing biolubricants from vegetable oil-based materials that would be more economical and greener, and will one day replace mineral oil-based lubricants with bio-based products in environmentally sensitive applications.

Acknowledgments: The authors (Gobinda Karmakar and Pranab Ghosh) are thankful to University Grants Commission, New Delhi for financial support.

Author Contributions: Gobinda Karmakar wrote the manuscript with the help of Pranab Ghosh and Brajendra K. Sharma. Brajendra K. Sharma has developed the idea and edited the article.

Conflicts of Interest: The authors declare no conflict of interest.

\section{References}

1. Ghosh, P.; Das, M.; Upadhyay, M.; Das, T.; Mandal, A. Synthesis and Evaluation of Acrylate Polymers in Lubricating Oil. J. Chem. Eng. Data 2011, 56, 3752-3758. [CrossRef]

2. Johnson, D.W.; Hils, J.E. Phosphate Esters, Thiophosphate Esters and Metal Thiophosphates as Lubricant Additives. Lubricants 2013, 1, 132-148. [CrossRef]

3. Boyde, S. Green lubricants. Environmental benefits and impacts of lubrication. Green Chem. 2002, 4, 293-307. [CrossRef]

4. Ripple, D.E.; Fuhrmann, J.F. Performance comparisons of synthetic and mineral oil crankcase lubricant base stocks. Lubr. Sci. 1989, 6, 209-232. [CrossRef]

5. Salimon, J.; Salih, N.; Yousif, E. Biolubricants: Raw materials, chemical modifications and environmental benefits. Eur. J. Lipid Sci. Technol. 2010, 112, 519-530. [CrossRef]

6. Salimon, J.; Abdullah, B.M.; Yusop, R.M.; Salih, N. Synthesis, reactivity and application studies for different biolubricants. Chem. Cent. J. 2014, 8, 16. [CrossRef] [PubMed]

7. Li, W.; Jiang, C.; Chao, M.; Wang, X. Natural Garlic Oil as a High-Performance, Environmentally Friendly, Extreme Pressure Additive in Lubricating Oils. ACS Sustain. Chem. Eng. 2014, 2, 798-803. [CrossRef]

8. Ossia, C.V.; Han, H.G.; Kong, H. Additive properties of saturated very long chain fatty acids in castor and jojoba oils. J. Mech. Sci. Technol. 2008, 22, 1527-1536. [CrossRef]

9. Erhan, S.Z.; Adhvaryu, A.; Sharma, B.K. Poly(hydroxy thioether) Vegetable Oil Derivatives Useful as Lubricant Additives. U.S. Patent 7,279,448 B2, 9 October 2007. 
10. Erhan, S.Z.; Doll, K.M.; Sharma, B.K. Method of Making Fatty Acid Ester Derivatives. U.S. Patent 8,173,825 B2, 8 May 2012.

11. Erhan, S.Z.; Doll, K.M.; Sharma, B.K. Method of Making Fatty Acid Ester Derivatives. U.S. Patent 20,080,154,053 A1, 26 June 2008.

12. Doll, K.M.; Sharma, B.K.; Suarez, P.A. Process to Prepare a Phosphorous Containing Vegetable Oil Based Lubricant Additive. U.S. Patent 8,822,712 B1, 2 September 2014.

13. Biswas, A.; Doll, K.M.; Cheng, H.N.; Sharma, B.K. Process for Preparation of Nitrogen-Containing Vegetable Oil-Based Lubricant Additive. U.S. Patent 8,841,470 B1, 23 September 2014.

14. Heise, G.L.; Sharma, B.K.; Erhan, S.Z. Boron Containing Vegetable Oil Based Antiwear/Antifriction Additive and Their Preparation. U.S. Patent 9,156,859 B2, 13 October 2015.

15. Erickson, F.L.; Anderson, R.E.; Landis, P.S. Vegetable Oil Derivatives as Lubricant Additives. U.S. Patent 5,282,989, 1 February 1994.

16. Erickson, F.L.; Anderson, R.E.; Landis, P.S. Meadowfoam Oil and Meadowfoam Oil Derivatives as Lubricant Additives. U.S. Patent 4,925,581, 15 May 1990.

17. Karmakar, G.; Ghosh, P. Soybean Oil as a Biocompatible Multifunctional Additive for Lubricating Oil. ACS Sustain. Chem. Eng. 2015, 3, 19-25. [CrossRef]

18. Ghosh, P.; Karmakar, G. Evaluation of sunflower oil as a multifunctional lubricating oil additive. Int. J. Ind. Chem. 2014, 5. [CrossRef]

19. Karmakar, G.; Ghosh, P. Green Additives for Lubricating Oil. ACS Sustain. Chem. Eng. 2013, 1, $1364-1370$. [CrossRef]

20. Ghosh, P.; Hoque, M.; Karmakar, G. Castor oil as potential multifunctional additive in the formulation of eco-friendly lubricant. Polym. Bull. 2017. [CrossRef]

21. Mofijur, M.; Masjuki, H.H.; Kalam, M.A.; Shahabuddin, M.; Hazrat, M.A.; Liaquat, A.M. Palm oil methyl ester and its emulsions effect on lubricant performance and engine components wear. Energy Procedia 2012, 14, 1748-1753. [CrossRef]

22. Liu, Z.; Sharma, B.K.; Erhan, S.Z.; Biswas, A.; Wang, R.; Schuman, T.P. Oxidation and low temperature stability of polymerized soybean oil-based lubricants. Thermochim. Acta 2015, 601, 9-16. [CrossRef]

23. Adhvaryu, A.; Erhan, S.Z.; Liu, Z.S.; Perez, J.M. Oxidation kinetic studies of unmodified and genetically modified vegetable oils using pressurized differential scanning calorimetry and nuclear magnetic resonance spectroscopy. Thermochim. Acta 2000, 364, 87-97. [CrossRef]

24. Fox, N.J.; Stachowiak, G.W. Vegetable oil-based lubricants-A review of oxidation. Tribol. Int. 2007, 40, 1035-1046. [CrossRef]

25. Shashidhara, Y.M.; Jayaram, S.R. Vegetable oils as a potential cutting fluid-An evolution. Tribol. Int. 2010, 43, 1073-1081. [CrossRef]

26. Erhan, S.Z.; Sharma, B.K.; Liu, Z.; Adhvaryu, A. Lubricant base stock potential of chemically modified vegetable oils. J. Agric. Food Chem. 2008, 56, 8919-8925. [CrossRef] [PubMed]

27. Campanella, A.; Rusto, E.; Baldessari, A.; Baltanás, M.A. Lubricants from chemically modified vegetable oils. Bioresour. Technol. 2010, 101, 245-254. [CrossRef] [PubMed]

28. Sharma, B.K.; Doll, K.M.; Erhan, S.Z. Ester hydroxy derivatives of methyl oleate: Tribological, oxidation and low temperature properties. Bioresour. Technol. 2008, 99, 7333-7340. [CrossRef] [PubMed]

29. Borugadda, V.B.; Goud, V.V. Epoxidation of Castor Oil Fatty Acid Methyl Esters (COFAME) as a Lubricant base Stock Using Heterogeneous Ion-exchange Resin (IR-120) as a Catalyst. Energy Procedia 2014, 54, 75-84. [CrossRef]

30. Baye, T.; Becker, H.C. Exploration of vernonia galamensis in Ethiopia, and variation in fatty acid compositionof seed oil. Genet. Resour. Crop Evol. 2005, 52, 805-811. [CrossRef]

31. Singh, R.K.; Padhi, S.K. Characterization of jatropha oil for the preparation of bio-diesel. Nat. Prod. Rad. 2009, 8, 127-132.

32. Chhetri, A.B.; Tango, M.S.; Budge, S.M.; Watts, K.C.; Islam, M.R. Non-Edible Plant Oils as New Sources for Biodiesel Production. Int. J. Mol. Sci. 2008, 9, 169-180. [CrossRef] [PubMed]

33. Murugesan, A.; Umarani, C.; Chinnusamy, T.R.; Krishnan, M.; Subramanian, R.; Neduzchezhain, N. Production and analysis of bio-diesel from non-edible oils-A review. Renew. Sustain. Energy Rev. 2009, 13, 825-834. [CrossRef] 
34. Ramos, M.J.; Fernández, C.M.; Casas, A.; Rodríguez, L.; Pérez, Á. Influence of fatty acid composition of raw materials on biodiesel properties. Bioresour. Technol. 2009, 100, 261-268. [CrossRef] [PubMed]

35. Tanveer, S.; Prasad, R. Enhancement of viscosity index of mineral base oils. Indian J. Chem. Technol. 2006, 13, 398-403.

36. Ghosh, P.; Hoque, M.; Karmakar, G.; Das, M.K. Dodecyl methacrylate and vinyl acetate copolymers as viscosity modifier and pour point depressant for lubricating oil. Int. J. Ind. Chem. 2017, 8, 197-205. [CrossRef]

37. Heraud, A.; Pouligny, B. How Does a “Cloud Point” Diesel Fuel Additive Work? J. Colloid Interface Sci. 1992, 153, 378-391. [CrossRef]

38. Sharma, B.K.; Stipanovic, A.J. Development of a new oxidation stability test method for lubricating oils using high-pressure differential scanning calorimetry. Thermochim. Acta 2003, 402, 1-18. [CrossRef]

39. Ghosh, P.; Pantar, A.V.; Rao, U.S.; Sarma, A.S. Shear stability of polymers used as viscosity modifiers in lubricating oils. Indian J. Chem. Technol. 1998, 5, 309-314.

40. Corma, A.; Iborra, S.; Velty, A. Chemical Routes for the Transformation of Biomass into Chemicals. Chem. Rev. 2007, 107, 2411-2502. [CrossRef] [PubMed]

41. Xia, Y.; Larock, R.C. Vegetable oil-based polymeric materials: Synthesis, properties, and applications. Green Chem. 2010, 12, 1893-1909. [CrossRef]

42. Hui, Y.H. Bailey's Industrial Oil and Fats Products, Edible Oil and Fat Products: General Application, 5th ed.; Wiley: Blackwell, UK, 1995; Volume 1, pp. 19-44.

43. Belgacem, M.N.; Gandini, A. Monomers, Polymers and Composites from Renewable Resources; Elsevier: Amsterdam, The Netherlands, 2008; pp. 39-66.

44. Wang, Y.N.; Chen, M.H.; Ko, C.H.; Lu, P.J.; Chern, J.M.; Wu, C.H.; Chang, F.C. Lipase catalyzed transesterification of tung and palm oil for biodiesel. In Proceedings of the World Renewable Energy Congress, Linköping, Sweden, 8-13 May 2011.

45. Güner, F.S.; Yağc1, Y.; Erciyes, A.T. Polymers from triglyceride oils. Prog. Polym. Sci. 2006, 31, 633-670. [CrossRef]

46. Rashid, U.; Anwar, F.; Knothe, G. Evaluation of biodiesel obtained from cottonseed oil. Fuel Process. Technol. 2009, 90, 1157-1163. [CrossRef]

47. Rani, S.; Joy, M.L.; Nair, K.P. Evaluation of physiochemical and tribological properties of rice bran oil-Biodegradable and potential base stoke for industrial lubricants. Ind. Crops Prod. 2015, 65, 328-333. [CrossRef]

48. Chauhan, P.S.; Chhibber, V.K. Epoxidation in karanja oil for biolubricant applications. Int. J. Pharm. Biol. Sci. Arch. 2013, 1, 61-70.

49. Meher, L.C.; Naik, S.N.; Das, L.M. Methanolysis of Pongamia pinnata (karanja) oil for production of biodiesel. J. Sci. Ind. Res. 2004, 63, 913-918.

50. Akbar, E.; Yaakob, Z.; Kamarudin, S.K.; Ismail, M.; Salimon, J. Characteristic and Composition of Jatropha Curcas Oil Seed from Malaysia and its Potential as Biodiesel Feedstock Feedstock. Eur. J. Sci. Res. 2009, 29, 396-403.

51. Aigbodion, A.I.; Pillai, C.K.S. Preparation, analysis and applications of rubber seed oil and its derivatives in surface coatings. Prog. Org. Coat. 2000, 38, 187-192. [CrossRef]

52. Aransiola, E.F.; Betiku, E.; Ikhuomoregbe, D.I.O.; Ojumu, T.V. Production of biodiesel from crude neem oil feedstock and its emissions from internal combustion engines. Afr. J. Biotechnol. 2012, 11, 6178-6186. [CrossRef]

53. Misra, R.D.; Murthy, M.S. Straight vegetable oils usage in a compression ignition engine: A review. Renew. Sustain. Energy Rev. 2010, 14, 3005-3013. [CrossRef]

54. Singh, S.P.; Singh, D. Biodiesel production through the use of different sources and characterisation of oils and their esters as the substitute of diesel: A review. Renew. Sustain. Energy Rev. 2010, 14, 200-216. [CrossRef]

55. Karmakar, A.; Karmakar, S.; Mukherjee, S. Properties of various plants and animals feedstocks for biodiesel production. Bioresour. Technol. 2010, 101, 7201-7210. [CrossRef] [PubMed]

56. Akhtar, N.; Adnan, Q.; Ahmad, M.; Mehmood, A.; Farzana, K. Rheological studies and characterization of different oils. J. Chem. Soc. Pak. 2009, 2, 31.

57. Verma, P.; Sharma, M.P.; Dwivedi, G. Evaluation and enhancement of cold flow properties of palm oil and its biodiesel. Energy Rep. 2016, 2, 8-13. [CrossRef]

58. Blin, J.; Brunschwig, C.; Chapuis, A.; Changotade, O.; Sidibe, S.; Noumi, E.; Girard, P. Characteristics of vegetable oils for use as fuel in stationary diesel engines-towards specifications for a standard in West Africa. Renew. Sustain. Energy Rev. 2013, 22, 580-597. [CrossRef] 
59. Harikrishnan, S.N.; Sabarish, R. Experimental Analysis of Direct Injection Diesel Engine Using Rubber Seed Oil. Middle-East J. Sci. Res. 2014, 20, 709-714.

60. Bello, E.I.; Otu, F. Physicochemical Properties of Rubber (Hevea brasiliensis) Seed Oil, Its Biodiesel and Blends with Diesel. Br. J. Appl. Sci. Technol. 2015, 6, 261-275. [CrossRef]

61. Padhi, S.K.; Singh, R.K. Optimization of esterification and transesterification of Mahua (Madhuca Indica) oil for production of biodiesel. J. Chem. Pharm. Res. 2010, 2, 599-608.

62. Ma, F.; Hanna, M.A. Biodiesel production: A review. Bioresour. Technol. 1999, 70, 1-15. [CrossRef]

63. Meher, L.C.; Sagar, D.V.; Naik, S.N. Technical aspects of biodiesel production by transesterification-a review. Renew. Sustain. Energy Rev. 2006, 10, 248-268. [CrossRef]

64. Musa, I.A. The effects of alcohol to oil molar ratios and the type of alcohol on biodiesel production using transesterification process. Egypt. J. Pet. 2016, 25, 21-31. [CrossRef]

65. Fabiano, B.; Reverberi, A.P.; Borghi, A.D.; Dovi, G. Biodiesel production via transesterification: Process safety insights from kinetic modeling. Theor. Found. Chem. Eng. 2012, 46, 673-680. [CrossRef]

66. Ji, H.; Zhang, X.; Tan, T. Preparation of a Water-Based Lubricant from Lignocellulosic Biomass and Its Tribological Properties. Ind. Eng. Chem. Res. 2017. [CrossRef]

67. Schäffner, B.; Blug, M.; Kruse, D.; Polyakov, M.; Köckritz, A.; Martin, A.; Rajagopalan, P.; Bentrup, U.; Brückner, A.; Jung, S.; et al. Synthesis and Application of Carbonated Fatty Acid Esters from Carbon Dioxide Including a Life Cycle Analysis. ChemSusChem 2014, 7, 1133-1139. [CrossRef] [PubMed]

68. Kenar, J.A.; Knothe, G.; Copes, A.L. Synthesis and characterization of dialkyl carbonates prepared from mid-, long-chain, and guerbet alcohols. J. Am. Oil Chem. Soc. 2004, 81, 285-291. [CrossRef]

69. Alam, M.; Akram, D.; Sharmin, E.; Zafar, F.; Ahmad, S. Vegetable oil based eco-friendly coating materials: A review article. Arab. J. Chem. 2014, 7, 469-479. [CrossRef]

70. Lligadas, G.; Ronda, J.C.; Galiá, M.; Cádiz, V. Renewable polymeric materials from vegetable oils: A perspective. Mater. Today 2013, 16. [CrossRef]

71. Samarth, N.B.; Mahanwar, P.A. Modified Vegetable Oil Based Additives as a Future Polymeric Material-Review. Open J. Org. Polym. Mater. 2015, 5, 1-22. [CrossRef]

72. Fukuda, H.; Kondo, A.; Noda, H. Biodiesel fuel production by transesterification of oils. J. Biosci. Bioeng. 2001, 92, 405-416. [CrossRef]

73. Lam, M.K.; Lee, K.T.; Mohamed, A.R. Homogeneous, heterogeneous and enzymatic catalysis for transesterification of high free fatty acid oil (waste cooking oil) to biodiesel: A review. Biotechnol. Adv. 2010, 28, 500-518. [CrossRef] [PubMed]

74. Macario, A.; Giordano, G.; Onida, B.; Cocina, D.; Tagarelli, A.; Giuffrè, A.M. Biodiesel production process by homogeneous/heterogeneous catalytic system using an acid-base catalyst. Appl. Catal. A Gen. 2010, 378, 160-168. [CrossRef]

75. Canakci, M.; Gerpen, J.V. Biodiesel production from oils and fats with high free fatty acids. Trans. ASAE 2001, 44, 1429-1436. [CrossRef]

76. Ejikeme, P.M.; Anyaogu, I.D.; Ejikeme, C.L.; Nwafor, N.P.; Egbuonu, C.A.C.; Ukogu, K.; Ibemesi, J.A. Catalysis in Biodiesel Production by Transesterification Processes-An Insight. J. Chem. 2010, 7, 1120-1132. [CrossRef]

77. Talukder, M.M.R.; Wu, J.C.; Lau, S.K.; Cui, L.C.; Shimin, G.; Lim, A. Comparison of Novozym 435 and Amberlyst 15 as Heterogeneous Catalyst for Production of Biodiesel from Palm Fatty Acid Distillate. Energy Fuels 2009, 23, 1-4. [CrossRef]

78. López, D.E.; Goodwin, J.G., Jr.; Bruce, D.A. Transesterification of triacetin with methanol on Nafion ${ }^{\circledR}$ acid resins. J. Catal. 2007, 245, 381-391. [CrossRef]

79. Furuta, S.; Matsuhashi, H.; Arata, K. Biodiesel fuel production with solid superacid catalysis in fixed bed reactor under atmospheric pressure. Catal. Commun. 2004, 5, 721-723. [CrossRef]

80. Helwani, Z.; Othman, M.R.; Aziz, N.; Kim, J.; Fernando, W.J.N. Solid heterogeneous catalysts for transesterification of triglycerides with methanol: A review. Appl. Catal. A Gen. 2009, 363, 1-10. [CrossRef]

81. Kim, H.K.; Kang, B.S.; Kim, M.J.; Lee, K.Y. Development of heterogeneous catalyst system for esterification of free fatty acid contained in used vegetable oil. Stud. Surf. Sci. Catal. 2004, 153, 201-204.

82. Chung, K.H.; Park, B.G. Esterification of oleic acid in soybean oil on zeolite catalysts with different acidity. J. Ind. Eng. Chem. 2009, 15, 388-392. [CrossRef] 
83. Peter, S.K.F.; Ganswindt, R.; Neuner, H.P.; Weidner, E. Alcoholysis of triacylglycerols by heterogeneous catalysis. Eur. J. Lipid Sci. Technol. 2002, 104, 324-330. [CrossRef]

84. Sulek, M.W.; Kulczycki, A.; Malysa, A. Assessment of lubricity of compositions of fuel oil with biocomponents derived from rape-seed. Wear 2010, 268, 104-108. [CrossRef]

85. Sukjit, E.; Dearn, K.D. Enhancing the lubricity of an environmentally friendly Swedish diesel fuel MK1. Wear 2011, 271, 1772-1777. [CrossRef]

86. Maleque, M.A.; Masjuki, H.H.; Haseeb, A.S.M.A. Effect of mechanical factors on tribological properties of palm oil methyl ester blended lubricant. Wear 2000, 239, 117-125. [CrossRef]

87. Masjuki, H.H.; Maleque, M.A. The effect of palm oil diesel fuel contaminated lubricant on sliding wear of cast irons against mild steel. Wear 1996, 198, 293-299. [CrossRef]

88. Masjuki, H.H.; Maleque, M.A. Investigation of the anti-wear characteristics of palm oil methyl ester using a four-ball tribometer test. Wear 1997, 206, 179-186. [CrossRef]

89. Malavolti, M.; Brandi, A.; Salvini, A.; Giomi, D. Transesterification of castor oil with trimethylchlorosilane: Simultaneous formation of fatty acid alkyl esters and $\alpha$-monochlorohydrin. RSC Adv. 2015, 5, 77341-77347. [CrossRef]

90. Madankar, C.S.; Pradhan, S.; Naik, S.N. Parametric study of reactive extraction of castor seed (Ricinus communis L.) for methyl ester production and its potential use as bio lubricant. Ind. Crops Prod. 2013, 43, 283-290. [CrossRef]

91. Shi, Y.J.; Minami, I.; Grahn, M.; Bjorling, M.; Larsson, R. Boundary and elastohydrodynamic lubrication studies of glycerol aqueous solutions as green lubricants. Tribol. Int. 2014, 69, 39-45. [CrossRef]

92. Langdon, W.K. Oxyalkylated Polyglycerols and Water-Based Lubricants Prepared Therefrom. U.S. Patent 4,265,774 A, 5 May 1981.

93. Rudnick, L.R. Synthetics, Mineral Oils and Bio-Based Lubricants Chemistry and Technology; CRC Press, Taylor \& Francis Group: Boca Raton, FL, USA, 2006; pp. 362-386, ISBN 978-1-57444-723-1.

94. Talukder, M.R.; Wu, J.C.; Chua, L.P.L. Conversion of Waste Cooking Oil to Biodiesel via Enzymatic Hydrolysis Followed by Chemical Esterification. Energy Fuels 2010, 24, 2016-2019. [CrossRef]

95. Chowdhury, A.; Mitra, D.; Biswas, D. Biolubricant synthesis from waste cooking oil via enzymatic hydrolysis followed by chemical esterification. J. Chem. Technol. Biotechnol. 2013, 88, 139-144. [CrossRef]

96. Vescovi, V.; Rojas, M.J.; Baraldo, A.; Botta, D.C.; Santana, F.A.M.; Costa, J.P.; Machado, M.S.; Honda, V.K.; Giordano, R.L.C.; Tardioli, P.W. Lipase-Catalyzed Production of Biodiesel by Hydrolysis of Waste Cooking Oil Followed by Esterification of Free Fatty Acids. J. Am. Oil Chem. Soc. 2016, 93, 1615-1624. [CrossRef]

97. Waghmare, G.V.; Rathod, V.K. Ultrasound assisted enzyme catalyzed hydrolysis of waste cooking oil under solvent free condition. Ultrason. Sonochem. 2016, 32, 60-67. [CrossRef] [PubMed]

98. Soares, D.; Pinto, A.F.; Gonçalves, A.G.; Mitchell, D.A.; Krieger, N. Biodiesel production from soybean soapstock acid oil by hydrolysis in subcritical water followed by lipase-catalyzed esterification using a fermented solid in a packed-bed reactor. Biochem. Eng. J. 2013, 81, 15-23. [CrossRef]

99. Luo, H.; Xue, K.; Fan, W.; Li, C.; Nan, G.; Li, Z. Hydrolysis of Vegetable Oils to Fatty Acids Using Brønsted Acidic Ionic Liquids as Catalysts. Ind. Eng. Chem. Res. 2014, 53, 11653-11658. [CrossRef]

100. Syaima, M.T.S.; Ong, K.H.; Noor, I.M.; Zamratul, M.I.M.; Brahima, S.A.; Hafizul, M.M. The synthesis of bio-lubricant based oil by hydrolysis and non-catalytic of palm oil mill effluent (POME) using lipase. Renew. Sustain. Energy Rev. 2015, 44, 669-675. [CrossRef]

101. Biswas, A.; Sharma, B.K.; Willett, J.L.; Erhan, S.Z.; Cheng, H.N. Soybean oil as a renewable feedstock for nitrogen-containing derivatives. Energy Environ. Sci. 2008, 1, 639-644. [CrossRef]

102. Yan, S.; Salley, S.O.; Simon, N.K.Y. Simultaneous transesterification and esterification of unrefined or waste

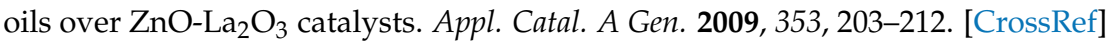

103. Fruth, A.; Strauss, J.; Stuhler, H. Process for the Preparation of Saturated Primary Fatty Amines by Hydrogenation of Unsaturated Fatty Acid Nitriles. U.S. Patent 5,175,370 A, 29 December 1992.

104. Lundgren, S. Fatty Amine Salts as Friction Modifiers for Lubricants. Patent WO 2,015,059,162 A1, 30 April 2015.

105. Lundgren, S. Fatty Amine Salts as Friction Modifiers for Lubricants. U.S. Patent 9,487,728 B2, 8 November 2016.

106. Laufenberg, A.; Preibsch, W.; Schmitz, K.H. Lubricant Concentrate and an Aqueous Lubricant Solution Based on Fatty Amines, a Process for Its Production and Its Use. U.S. Patent 5,474,692 A, 12 December 1995. 
107. Pramanik, M.; Mendon, S.K.; Rawlins, J.W. Vegetable Oil Based Fatty Amide as Hydrophobes in Associative Thickener. J. Appl. Polym. Sci. 2013, 1530-1538. [CrossRef]

108. Feairheller, S.H.; Bistline, R.G., Jr.; Bilyk, A.; Dudley, R.L.; Kozempel, M.F.; Haas, M.J. A novel technique for the preparation of secondary fatty amides. J. Am. Oil Chem. Soc. 1994, 71, 863-866. [CrossRef]

109. Kopylov, L.I.; Shekhter, Y.N.; Gureev, A.A.; Bakaleinikov, M.B. Physicochemical and functional properties of mixtures of AKOR-1 inhibitor and alkanolamides. Chem. Technol. Fuels Oils 1980, 16, 62-64. [CrossRef]

110. Kelley, M.J.; Robinson, E.A. Composition for Lubricating and Softening Textile Fibers. U.S. Patent 2,340,881, 8 February 1944.

111. Gentry, D.R.; Stehlin, M.P.; Weers, J.J. Fatty Acid Amide Lubricity Aids and Related Methods for Improvement of Lubricity of Fuels. U.S. Patent 6,562,086 B1, 13 May 2003.

112. Kammann, K.P., Jr. Modified Fatty Amides and Sulfurized Fatty Oils as Lubricant Additives. U.S. Patent 4921624 A, 1 May 1990.

113. Sánchez, M.A.; Mazzieri, V.A.; Vicerich, M.A.; Vera, C.R.; Pieck, C.L. Influence of the Support Material on the Activity and Selectivity of Ru-Sn-B Catalysts for the Selective Hydrogenation of Methyl Oleate. Ind. Eng. Chem. Res. 2015, 54, 6845-6854. [CrossRef]

114. Giraldo, L.; Camargo, G.; Tirano, J.; Moreno-Pirajan, J.C. Synthesis of Fatty Alcohol from Oil Palm Using a Catalyst of Ni-Cu Supported onto Zeolite. J. Chem. 2010, 7, 1138-1147. [CrossRef]

115. Mueller, H.; Herold, C.P.; Tapavicza, S.V. Use of Selected Fatty Alcohols and Their Mixtures with Carboxylic Acid Esters as Lubricant Components in Water-Based Drilling Fluid Systems for Soil Exploration. U.S. Patent 6,716,799 B1, 6 April 2004.

116. Cai, S.; Wang, L. Epoxidation of Unsaturated Fatty Acid Methyl Esters in the Presence of $\mathrm{SO}_{3} \mathrm{H}$-functional Brønsted Acidic Ionic Liquid as Catalyst. Chin. J. Chem. Eng. 2011, 19, 57-63. [CrossRef]

117. Abdullah, B.M.; Salimon, J. Epoxidation of Vegetable Oils and Fatty Acids: Catalysts, Methods and Advantages. J. Appl. Sci. 2010, 10, 1545-1553.

118. Saithai, P.; Lecomte, J.; Dubreucq, E.; Tanrattanakul, V. Effects of different epoxidation methods of soybean oil on the characteristics of acrylated epoxidized soybean oil-co-poly(methyl methacrylate) copolymer. eXPRESS Polym. Lett. 2013, 7, 910-924. [CrossRef]

119. Dinda, S.; Goud, V.V.; Patwardhan, A.V.; Pradhan, N.C. Selective epoxidation of natural triglycerides using acidic ion exchange resin as catalyst. Asia-Pac. J. Chem. Eng. 2011, 6, 870-878. [CrossRef]

120. Guidotti, M.; Gavrilova, E.; Galarneau, A.; Coq, B.; Psaro, R.; Ravasio, N. Epoxidation of methyl oleate with hydrogen peroxide. The use of Ti-containing silica solids as efficient heterogeneous catalysts. Green Chem. 2011, 13, 1806-1811. [CrossRef]

121. Tiozzo, C.; Bisio, C.; Carniato, F.; Marchese, L.; Gallo, A.; Ravasio, N.; Psaro, R.; Guidotti, M. Epoxidation with hydrogen peroxide of unsaturated fatty acid methyl esters over $\mathrm{Nb}(\mathrm{V})$-silica catalysts. Eur. J. Lipid Sci. Technol. 2013, 115, 86-93. [CrossRef]

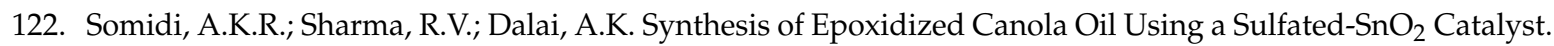
Ind. Eng. Chem. Res. 2014, 53, 18668-18677. [CrossRef]

123. Leng, Y.; Zhao, J.; Jiang, P.; Wang, J. Amphiphilic Polyoxometalate-Paired Polymer Coated $\mathrm{Fe}_{3} \mathrm{O}_{4}$ : Magnetically Recyclable Catalyst for Epoxidation of Bio-Derived Olefins with $\mathrm{H}_{2} \mathrm{O}_{2}$. ACS Appl. Mater. Interfaces 2014, 6, 5947-5954. [CrossRef] [PubMed]

124. Kyriakidis, N.B.; Katsiloulis, T. Calculation of Iodine Value from Measurements of Fatty Acid Methyl Esters of Some Oils: Comparison with the Relevant American Oil Chemists Society Method. J. Am. Oil Chem. Soc. 2000, 77, 1235-1238. [CrossRef]

125. Alves, S.M.; Barros, B.S.; Trajano, M.F.; Ribeiro, K.S.B.; Moura, E. Tribological behavior of vegetable oil-based lubricants with nanoparticles of oxides in boundary lubrication conditions. Tribol. Int. 2013, 65, 28-36. [CrossRef]

126. Schafer, V.; Kohler, R.; Pauli, A.; Fessenbecker, A. Corrosion Protection Additives Based on Epoxides. U.S. Patent 5,368,776 A, 29 November 1994.

127. Rowland, R.G.; Migdal, C.A. Epoxidized Ester Additives for Reducing Lead Corrosion in Lubricants and Fuels. Patent EP 1805284A1, 11 July 2007.

128. Lathi, P.S.; Mattiasson, B. Green approach for the preparation of biodegradable lubricant base stock from epoxidized vegetable oil. Appl. Catal. B Environ. 2007, 69, 207-212. [CrossRef] 
129. Sharma, B.K.; Adhvaryu, A.; Erhan, S.Z. Synthesis of Hydroxy Thio-ether Derivatives of Vegetable Oil. J. Agric. Food Chem. 2006, 54, 9866-9872. [CrossRef] [PubMed]

130. Sharma, B.K.; Adhvaryu, A.; Erhan, S.Z. Friction and wear behavior of thioether hydroxy vegetable oil. Tribol. Int. 2009, 42, 353-358. [CrossRef]

131. Varshney, H.; Ahmad, A.; Rauf, A. Ring Opening of Epoxy Fatty Esters by Nucleophile to Form the Derivatives of Substituted $\beta$-Amino Alcohol. Food Nutr. Sci. 2013, 4, 21-24. [CrossRef]

132. Blattmann, H.; Fleischer, M.; Bähr, M.; Mülhaupt, R. Isocyanate- and Phosgene-Free Routes to Polyfunctional Cyclic Carbonates and Green Polyurethanes by Fixation of Carbon Dioxide. Macromol. Rapid Commun. 2014, 35, 1238-1254. [CrossRef] [PubMed]

133. Doll, K.M.; Erhan, S.Z. Synthesis of Carbonated Fatty Methyl Esters Using Supercritical Carbon Dioxide. J. Agric. Food Chem. 2005, 53, 9608-9614. [CrossRef] [PubMed]

134. Comerford, J.W.; Ingram, I.D.V.; North, M.; Wu, X. Sustainable metal-based catalysts for the synthesis of cyclic carbonates containing five-membered rings. Green Chem. 2015, 17, 1966-1987. [CrossRef]

135. Martín, C.; Fiorani, G.; Kleij, A.W. Recent Advances in the Catalytic Preparation of Cyclic Organic Carbonates. ACS Catal. 2015, 5, 1353-1370. [CrossRef]

136. Han, L.; Park, S.W.; Park, D.W. Silica grafted imidazolium-based ionic liquids: Efficient heterogeneous catalysts for chemical fixation of $\mathrm{CO}_{2}$ to a cyclic carbonate. Energy Environ. Sci. 2009, 2, 1286-1292. [CrossRef]

137. Tamami, B.; Sohn, S.; Wilkes, G.L. Incorporation of carbon dioxide into soybean oil and subsequent preparation and studies of nonisocyanate polyurethane networks. J. Appl. Polym. Sci. 2004, 92, 883-891. [CrossRef]

138. Doll, K.M.; Erhan, S.Z. The improved synthesis of carbonated soybean oil using supercritical carbon dioxide at a reduced reaction time. Green Chem. 2005, 7, 849-854. [CrossRef]

139. Tenhumberg, N.; Büttner, H.; Schäffner, B.; Kruse, D.; Blumensteinc, M.; Werner, T. Cooperative catalyst system for the synthesis of oleochemical cyclic carbonates from $\mathrm{CO}_{2}$ and renewable. Green Chem. 2016, 18, 3775-3788. [CrossRef]

140. Polyakov, M.; Schäffner, B.; Kruse, D.; Martin, A.; Köckritz, A. Epoxide and cyclic carbonate with diisononyl succinate backbone as phthalate-free plasticizers. Tetrahedron Lett. 2016, 57, 964-968. [CrossRef]

141. Kathalewar, M.S.; Joshi, P.B.; Sabnis, A.S.; Malshe, V.C. Non-isocyanate polyurethanes: From chemistry to applications. RSC Adv. 2013, 3, 4110-4129. [CrossRef]

142. Arca, M.; Sharma, B.K.; Perez, J.M.; Doll, K.M. Gear oil formulation designed to meet bio-preferred criteria as well as give high performance. Int. J. Sustain. Eng. 2013, 6, 326-331. [CrossRef]

143. Karmakar, G.; Ghosh, P. Atom Transfer Radical Polymerization of Soybean Oil and Its Evaluation as a Biodegradable Multifunctional Additive in the Formulation of Eco-Friendly Lubricant. ACS Sustain. Chem. Eng. 2016, 4, 775-781. [CrossRef]

144. Upadhyay, M.; Karmakar, G.; Kapur, G.S.; Ghosh, P. Multifunctional greener additives for lubricating oil. Polym. Eng. Sci. 2017. [CrossRef]

145. Biresaw, G.; Asadauskas, S.J.; McClure, T.G. Polysulfide and biobased extreme pressure additive performance in vegetable vs paraffinic base oils. Ind. Eng. Chem. Res. 2012, 51, 262-273. [CrossRef]

146. Landis, P.S. Telomerized Triglyceride Vegetable Oil for Lubricant Additives. U.S. Patent 5,229,023, 20 July 1993.

147. Tian, Q.; Larock, R.C. Model studies and the ADMET polymerization of soybean oil. J. Am. Oil. Chem. Soc. 2002, 79, 479-488. [CrossRef]

148. Rybak, A.; Fokou, P.A.; Meier, M.A.R. Metathesis as a versatile tool in oleochemistry. Eur. J. Lipid Sci. Technol. 2008, 110, 797-804. [CrossRef]

149. Mutlu, H.; Meier, M.A.R. Ring-opening metathesis polymerization of fatty acid derived monomers. J. Polym. Sci. Part A Polym. Chem. 2010, 48, 5899-5906. [CrossRef]

150. Mohan, N.; Natarajan, S.; KumareshBabu, S.P.; Siddaramaiah. Investigation on Sliding Wear Behaviour and Mechanical Properties of Jatropha Oil Cake-Filled Glass-Epoxy Composites. J. Am. Oil Chem. Soc. 2011, 88, 111-117. [CrossRef]

(C) 2017 by the authors. Licensee MDPI, Basel, Switzerland. This article is an open access article distributed under the terms and conditions of the Creative Commons Attribution (CC BY) license (http://creativecommons.org/licenses/by/4.0/). 